\title{
THE RUSSIAN ORTHODOX CHURCH IN THE EDUCATIONAL SPACE OF MODERN RUSSIA
}

\author{
Bogdan Ershov', Ekaterina Volkova ${ }^{2}$, Elena Frolova ${ }^{3}$, Olga Volokitina ${ }^{4}$, Sergey \\ Volkov ${ }^{5}$ \\ ${ }^{1}$ Doctor of Historical Sciences, Professor, Voronezh State Technical University, 20 years of \\ October street, 84,Voronezh, Russia, E-mail: bogdan.ershov@yandex.ru \\ ${ }^{2}$ Candidate of Historical Sciences, Associate Professor, Voronezh State Technical University, 20 \\ years of October Street, 84, Voronezh, Russia, E-mail: volkne@bk.ru \\ ${ }^{3}$ Candidate of Philosophy, Associate Professor, Voronezh State Technical University, 20 years of \\ October Street, 84, Voronezh, Russia, E-mail: frolov-elen@yandex.ru \\ ${ }^{4}$ Candidate of Technical Sciences, Associate Professor, Voronezh State Technical University, 20 \\ years of October Street, 84, Voronezh, Russia, E-mail: dixi.o@mail.ru \\ ${ }^{5}$ Bachelor, Voronezh State Technical University, 20 years of October Street, 84, Voronezh, Russia, \\ E-mail: Sergeyvolkov2001@gmail.com
}

\begin{abstract}
The article considers the pedagogical heritage of the Russian Orthodox Church, which contains an inexhaustible educational potential that is not subject to ideological fluctuations, since it is based on unchanging values. In Orthodoxy and the harsh Russian nature lie the origins of the Russian soul and the keys to its understanding. In Orthodoxy, Russian military commanders and soldiers, writers and artists, scientists, naturalists, doctors, devotees of piety were brought up.

At present, the Orthodox Church can offer a holistic, positive educational system that has been tested for ten centuries. The interaction of the state and the Russian Orthodox Church is a unique phenomenon of joint, complementary resources to address critical issues of a moral nature.
\end{abstract}

Keywords: church, education, science, society, state.

\section{INTRODUCTION}

In recent years, the problem of spiritual and moral development and upbringing of new generations on the basis of traditional values has been a subject of public concern, which is reflected in journalism, heated public discussions, public initiative movements, relevant pedagogical experience, and scientific and pedagogical research.

In public discussions, it turned out that society associates expectations with the traditional values in the field of counteracting the negative phenomena of our time, such as various addictions, infantilization, criminalization, and others. According to the Prosecutor General's Office of the Russian Federation, the level 
of juvenile delinquency in the country remains high.

The pedagogical opportunities of the school and family are insufficient for the organization of spiritual and moral education. Modernity is characterized by a significant influence of the social and media environment of a consumer society on the formation of a child's personality. The prevailing ideas about the spiritual and moral world of a person and the ways of his development that prevailed in the past decades in the domestic pedagogical community turned out to be insufficient for the pedagogical practice of public education guided by traditional social ideals focused on the "eternal values" of altruism, social solidarity, mercy, and serving the common good. Meanwhile, the weight of these values in society is high and it is they that make up the value basis of the constitutional system of the Russian Federation. Therefore, it is necessary to find mechanisms for transmitting these values to new generations in the current conditions.

\section{METHODOLOGY}

The methodological basis of the article is the principles of historicism, scientific objectivity, systematic and interdisciplinary research. The principle of historicism allows you to explore the problem of reforming the education system in the Russian Orthodox Church in the context of a specific socio-political reality, considering not only government plans, but also public opinion.

Based on the principle of scientific objectivity and systematicity, taking into account different points of view, a holistic picture of events is recreated. The interdisciplinary nature of the study makes it possible to use the methods of related sciences (sociology, statistics, economics) to analyze the problem.

\section{DISCUSSION}

The basis of the study is scientific works on the problems of spiritual and moral education, development and formation of personality in various spheres of life. Theoretical and pedagogical thought of the domestic pedagogical tradition, considering spiritual and moral education as a key element of education, is presented in the works: K.D. Ushinsky, N.I. Pirogov, P.F. Kaptereva, V.A. Sukhomlinsky and others. Philosophical and pedagogical issues of education are the studies of such scientists as G.S. Vinsky, B.C. Bezrukova, Yu.K. Babansky, E.V. Bondarevskaya, I.A. Ilyin, V.V. Kraevsky, B.T. Likhachev, A.B. Mudrik, V.I. Slobodchikov et al. Theoretical studies of the resource value of traditions for the development of education and ways to integrate value systems of tradition into modern education are reflected in the works of A. Ya. Danilyuk, M.V. Zakharchenko, C. B. Zholovana, T.I. Petrakova, E.V. Shestun.

In domestic psychology, in the works of B.S. Brother, F.E. Vasilyuka, A.A. Gosteva, V.P. Zinchenko, E.I. Isaev, B.V. Nichiporova, V.I. Slobodchikova, L.F. Shekhovtsova and others consider the formation of the spiritual, value-semantic sphere of personality as a special form of rational knowledge about the formation of the subjective spirit of a person within his individual life. Methodological developments and methodological recommendations on spiritual and moral education in pedagogical practice are presented in the works of V.V. Abramenkova, V.A. Belyaeva, T.I. Vlasova, A.A. Makarenya, V.V. Medushevsky, V.M. Menshikova, I.V. Metlika, T.I. Petrakova, T.V. Sklyarova, I.A. Solovtsova. Issues of organization and management of education are reflected in the works: D.A. Novikova M.I. Rozhkova, N.M. Rosenberg, A.I. Subetto, A.B. Tmenova B.S. Cherepanova, E.V. Yakovleva.

\section{RESULTS}

The study showed that the problem of the interaction of the state education system and traditional religious organizations is relevant in the social, cultural, managerial and pedagogical aspects. The importance of the issues raised in the study is confirmed by events in the sociocultural environment, in the appeal of many researchers to the search for adequate forms of spiritual and moral education of the younger generation, the introduction of the basic subject area "Fundamentals of the spiritual and moral culture of the peoples of Russia" into the basic curriculum of general education. The resolution of these problems is possible with the development of interaction between the state education system and the Russian Orthodox Church as carriers of basic national values.

This study was aimed at studying the interaction of the state education system and the Russian Orthodox Church in the field of spiritual and moral education of the younger generation, search and development of mechanisms that can include in the content of modern education the experience of the Russian Orthodox Church in the field of spiritual and moral education, confirming its effectiveness and in modern conditions. Thus, the study is aimed at finding the foundations, conditions and means of harmonious, productive, fruitful cooperation between the state education system and the Russian Orthodox Church, where the basis of interaction is a single worldview, the conditions are organizational and pedagogical conditions, and the 
means are agreed upon management mechanisms.

The theoretical and practical work carried out to study the subject of research allowed us to confirm the substantiated hypothesis and come to the following general conclusions:

1. The essence of modern relations between the state education system and the Russian Orthodox Church is a coordinated, jointly distributed activity to develop common ideas about the basic meanings of modern education, the spiritual and moral formation of the individual, the worldview foundations of modern Russian education and the national educational ideal, as well as building educational practice, which lays down the system of relations of the individual to society, the state, the church, and to man.

2. The content of the interaction of the state education system and the Russian Orthodox Church at present consists in the implementation of jointly developed methods and means of introducing into the content of modern education the experience of spiritual and moral education of the younger generation accumulated in Russia.

\section{CONCLUSION}

The revival of the spirituality of Russian society, the education of the younger generations of Russian citizens on the basis of high moral principles seems possible only with the active participation of the Russian Orthodox Church as an institution that preserves the foundations of the traditional worldview and value system to the greatest extent.

The desecularization of Russian society is not identical to its demodernization, since the Church does not reject the need for political and economic transformations, the development of science and technology, and the introduction of innovative components in the life of the state and society. The church is opposed to the negative consequences that inevitably arise in the process of modernization, especially "catching up" modernization, when the question arises of either the actual loss of national identity or the country's development along the path of combining the advanced achievements of the world community with national traditions and cultural values.

\section{REFERENCE LIST}

Bakhtin, Viktor Viktorovich (2020) Art Associations of the Central Chernozem Region in the Late XIX First Third of the XX Century. Bulletin Social-Economic and Humanitarian Research. Volume 6, Number 8. Pp. 33 - 43. doi: 10.5281/zenodo.3733601 (in Russ).

Bondarevskaya E. V. (1999) Pedagogy: personality in humanistic theories and systems of education. Uchitel. 560 p. (in Russ).

Cherepanov B. C. (1999) The problem of measurement in pedagogy: a conceptual and programmatic approach. Education and science. № 1. Pp. 159-164. (in Russ).

Ershov B.A. (2010) The Russian Orthodox Church and secular power in the Voronezh province in the XIX early XX centuries. GOU VPO "Voronezh State Technical University". Voronezh. 167 p. (in Russ).

Ershov B.A. (2010) The system of spiritual education in Voronezh province in the 19th century. Education and Society. №. 5 (64). Pp. 105-108. (in Russ).

Ershov B.A., Fursov V.N. (2018) The Russian Church in the State Mechanism of Russia. Bulletin SocialEconomic and Humanitarian Research. № 1. Pp. 32-37. (in Engl).

Ershov B.A., Perevozchikova L.S., Romanova E.V. (2019) Globalization and Intensification of Spiritual Values in Russia in the Philosophical Aspect. 6th International Conference on Education and Social Sciences Abstracts \& Proceedings. Pp. 208-212. (in Engl).

Ershov B.A., Perevozchikova L.S., Romanova E.V., Ashmarov I.A. (2019) The Concept of Spirituality in Social Philosophy. Smart Innovation, Systems and Technologies. T. 139. Pp. 688-694. (in Engl).

Isaev E. (2012) Introduction to the anthropology of education. monograph. Birobidzhan: publishing house of Sholom Aleichem vocational school. 215 p. (in Russ).

Kozyrev F. N. (2006) Religion as a subject of study: the experience of constructing a phenomenological 
model. Bulletin of Orenburg state University. № 2 (52). Vol. 1: Humanities. Pp. 57-66. (in Russ).

Novikov D. A. (2007) Project Management: organizational mechanisms. 140 p. (in Russ).

Okolelova E.Yu. (2006) Sustainability of economic processes and assessment of their predictability. Bulletin of Tula State University. Series: Construction, architecture and restoration. Pp. 146-151. (in Russ).

Perevozchikova L.S., Ershov B.A., Ashmarov I.A., Volkova E.A. (2017) Role of Russian Orthodox Church in life of peasants in Russia in XIX-the beginning of the XX-th centuries Bylye Gody. Russian historical journal. №. 43 (1). Pp. 121-128. (in Engl).

Pogorelov S. T. (2005) Fundamentals of Orthodox anthropology and pedagogy. Education and the future of Russia: collection of materials of the seminar. P. 103-117. (in Russ).

Romanova E.V., Perevozchikova L.S., Ershov B.A. (2017) The Lifestyle of the Human Being in the Information Society. 3rd International Conference on Advances in Education and Social Sciences Proceedings of ADVED Pp. 950-954. (in Engl).

Trostnikov V. N. (2004) Orthodox civilization. Siberian Barber. 272 p. (in Russ).

Volkova E.A., Frolova E.V., Ashmarov I.A. (2015) To the question of the formation of trends in the higher education system in the framework of modern globalization processes. Modern problems of science and education. №. 1-1. P. 975. (in Russ).

Zakharchenko M. V. (2002) Tradition in history: experience of typological interpretation. Saint Petersburg: Spbgupm. 228 p. (in Russ). 